ORIGINAL ARTICLE

\title{
The Impact of Malnutrition on the Increasing Risk of Bronchopneumonia Among Under Five-Year children
}

\author{
INTAN MUTIARA PUTRI ${ }^{1}$, ADE NOPRIYANTI² \\ ${ }^{1,2}$ Faculty of Health Sciences, Universitas 'Aisyiyah Yogyakarta, Indonesia \\ Coresponden author to Intan Mutiara Putri : intan.mutiaraputri@unisayogya.ac.id
}

\begin{abstract}
Background: Bronchopneumoniabecomes, one of the infectious diseases, is causing mortality in under five-year children. One of the risk factors of pneumonia in under five-year children is nutritional status. One of the types of pneumonia is the inflammation occurred on the tip of the bronchioles.

Aim: This research aimed to observe the relation of nutritional status and bronchopneumonia among under fiveyear children.

Method: This research had been approved by the Research Ethics Committee in Universitas 'Aisyiyah Yogyakarta. This control case research was conducted in the Public Regional Hospital of Panembahan Senopati, Bantul Yogyakarta. The study used 86 respondents (under five-year children) aged 12 to 60 months suffering from bronchopneumonia and 86 respondents (under five-year children) with pneumonia with the same ages as the previous one. The respondents were found using the random sampling technique listed in this research. The data were collected from the secondary data from the medical record.

Results: The chi-square statistical test result showed that the under five-year children with the malnutrition had three times higher risk of suffering bronchopneumonia than those with good nutritional status ( $p$-value: 0.001 and 95\% Cl: 1611-5.578).

Keywords: Nutritional Status, Bronchopneumonia, Under Five-Year Children
\end{abstract}

\section{INTRODUCTION}

Acute respiratory infection is one of the world's severe problems, as seen from the high mortality rate caused by pneumonia in many countries. World Health Organization (WHO) revealed that almost six million under five-year children died in $2015.16 \%$ of that number was caused by pneumonia [1]. Based upon the Indonesia Health Profile in 2016, the mortality related to pneumonia more frequently occurred in children aged 1-4 years old, representing $0.13 \%$ compared to the infants with a percentage of $0.06 \%$ [2]. In 2016, the pneumonia rate among the under five-year children in Yogyakarta was 3741 (or 28.12\%). Bantul Regency dominated this rate with the total pneumonia of $744(19,8 \%)$ [3]. A child suffering from pneumonia can be differentiated based upon its inflammation, namely, bronchiolitis and pneumonia [4]. Bronchopneumonia is one type of pneumonia that occurred on the bronchioles tip, blocked by exudate mucopurulent and creating the consolidated blotches in the lobe. Bronchopneumonia is more frequently caused by secondary infection towards any states weakening the body immune; however, it also can be caused by primary infection commonly found in children [5]. This research aimed to observe the relation of nutritional status and bronchopneumonia among under five-year children.

\section{METHOD}

Type and Place of Research. The research on the control case was conducted in the Public RegionalHospital of Panembahan Senopati Bantul. The research populations were 401 under five-year children aged 12-60 months suffering from bronchopneumonia and pneumonia. Case definitions: (A) bronchopneumonia: child below five years of age with fast breathing, wheeze, coryza, and radiological evidence of bronchiolitis, e.g., hyperinflation of the chest. (B) Pneumonia: child below five years of age with cough, fast breathing, lower chest wall indrawing, fever, coarse crackles on auscultation, and radiological evidence of pneumonia-like consolidation or periheliainfiltrate. Sampling: the inclusion criteria were the under-five-year children aged 12-60 months that met the definition of a case of bronchopneumonia or pneumonia - apart from sex. The exclusion criteria were the under-five-year children who have congenital heart disease or other congenital anomalies and suffering from chronic diseases such as Tuberculosis, thalassemia, and mal-absorption syndrome. The incomplete medical record here was eliminated from this research. Total respondents fulfilling the inclusion and exclusion criteria were 172 divided into the group of the case (86 respondents) and a group of control (86 respondents) that had been randomly selected in this research. Data collection and data analysis of research: data collection used the medical records, and data analysis used Chi-Square with a level of confidence of $95 \%$. The Ethics Committee of research: The ethics committee had approved this research from Universitas 'Aisyiyah Yogyakarta.

\section{RESULTS AND DISCUSSION}

Table 1 shows that most of the under-five-year children diagnosed with bronchopneumonia were in the group of age toddlers (12-36 months) with a total of 67 respondents $(51,1 \%)$ and by sex, it was dominated by male with a total of 50 respondents $(53,8 \%)$.

Age influenced the body immune mechanism of a person. The younger the age of children, the more prone they will be infected as the immune system in a child in the first year to the fifth year is still immature. The prone of infection in the under-five-year children is also lower than that of the younger ones. The under-five-year children who frequently suffer from pneumonia are in the range of 13-28 months [6]. The male child is more prone to suffer from 
pneumonia due to the physical difference in the respiratory tract anatomy between boys and girls. In general, in a specific size, boys' respiratory tract is smaller than girls [7]. This can increase the frequency of respiratory tract disease. It is seven times riskier for the male infant to suffer from pneumonia than the female one [8]. Many factors are causing the male to be more prone to suffer the infectious disease, such as the differences in hormones, pollution exposure, the difference in parenting, and the immune system in boys [9].

Table 1. Distribution of Characteristics of respondent

\begin{tabular}{|c|c|c|c|c|c|c|}
\hline \multirow{3}{*}{$\begin{array}{l}\text { Characteristics c of } \\
\text { Respondent }\end{array}$} & \multicolumn{4}{|c|}{ Type of pneumonia } & \multirow[t]{3}{*}{$\mathrm{n}$} & \multirow[t]{3}{*}{$\%$} \\
\hline & \multicolumn{2}{|c|}{ Bronchopneumonia n (86) } & \multicolumn{2}{|c|}{ Pneumonia n (86) } & & \\
\hline & $(\mathrm{f})$ & $(\%)$ & $(\mathrm{f})$ & $(\%)$ & & \\
\hline \multicolumn{7}{|l|}{ Age } \\
\hline Toddlers & 67 & 51.1 & 64 & 48.9 & 131 & 76.2 \\
\hline $\mathrm{P}$ reschool & 19 & 46.3 & 22 & 53.7 & 41 & 23.8 \\
\hline \multicolumn{7}{|l|}{ Sex } \\
\hline Male & 50 & 53.8 & 43 & 46.2 & 93 & 54.1 \\
\hline
\end{tabular}

Table 2. Distribution nutritional status

\begin{tabular}{|l|l|l|}
\hline Nutritional status & Frequency & Percentage (\%) \\
\hline Malnutrition & 131 & 76.2 \\
\hline Good nutrition & 41 & 23.8 \\
\hline Total & 172 & 100 \\
\hline
\end{tabular}

Table 2 shows that the nutritional status in the underfive-year children in which most of the respondents had malnutrition was as many as 131 respondents (76.2\%). Nutritional consumption is highly influential to the nutritional status of a person in which the nutritional status is a base for each individual's health. In addition to the impact on infectious disease, nutrition can also affect developing a child's brain and attitude, work competence, and productivity. It is affirmed that the infants with good nutritional status will have a development five times higher than infants with malnutrition [10]. If the nutritional status is getting worse, then the body's reaction will decrease. Then, the body's capability for self-defense from the attack of infection will also decrease. This occurs due to antibody formation that is disturbed or hindered, and finally, the production of antibodies would decrease. This would cause the body more prone to be attacked by the infection [11].

Table 3. DistributionType of pneumonia

\begin{tabular}{|l|l|l|}
\hline Type of pneumonia & Frequency & Percentage (\%) \\
\hline Bronchopneumonia & 86 & 50 \\
\hline Pneumonia & 86 & 50 \\
\hline Total & 172 & 100 \\
\hline
\end{tabular}

Table 3 shows that 86 respondents (50\%) suffered from bronchopneumonia, similar to those suffering from pneumonia as many as 86 respondents (50\%). Table 4 shows that the result of the statistic test of chi-square showed the $p$-value of 0.001 . Thus, it can be concluded that there was a relationship between the nutritional status and type of pneumonia. The infant with malnutrition had a 2.998 times higher risk of suffering from bronchopneumonia $(95 \% \mathrm{Cl}: 1.611-5.578)$ than the infant with good nutrition. This research supports Calder's (2013) theory that in an infant with malnutrition, the immune system will decrease and make it easier to be infected with pneumonia as one of the infectious diseases [12]. Malnutrition will hinder the specific antibody formation and disturb the lung defense of a child. The malnutrition experienced by children will cause disorder in the respiratory tract, and then it can disturb the physiological process of protection to the respiratory tract to the disease agent. As a result, the children cannot remove the disease agent and become the factor of the blockage in the respiratory tract [12]. Besides, in research, Scott (2008) showed that a child with malnutrition is more prone to be attacked by pneumonia than the one with an excellent nutritional status [13]. The result of the research found that most of the under-five-year children with pneumonia had malnutrition. It happens because the under-five-year child tends to have no appetite, which leads to malnutrition [14]. The other risk factors might include breastfeeding, cigarette smoke exposure, the previous record of vaccination, and concomitant infection such as conjunctivitis and otitis that can be the significant factors for the respiratory infection. The role of the risk factors towards the increase of pneumonia in children, as reported, is malnutrition [15].

\section{CONCLUSION}

Malnutrition can increase three times higher risk to suffer from bronchopneumonia among under-five-year children. Enhancing the knowledge of mothers about the awareness on the risk factor in the prevention of bronchopneumonia can help to reduce the exposure in under five-year children Acknowledgements: This research wassupported by Universitas 'Aisyiyah Yogyakarta Indonesia.

Table 4. Relationship between nutritional status and type of pneumonia

\begin{tabular}{|c|c|c|c|c|c|c|c|c|}
\hline \multirow{3}{*}{$\begin{array}{l}\text { Nutritional } \\
\text { status }\end{array}$} & \multicolumn{8}{|c|}{ Type of pneumonia } \\
\hline & \multicolumn{2}{|c|}{ Bronchopneumonia } & \multicolumn{2}{|c|}{ Pneumonia } & \multicolumn{2}{|l|}{ Total } & \multirow[t]{2}{*}{$p$-value } & \multirow[t]{2}{*}{ OR } \\
\hline & $f$ & $\%$ & $f$ & $\%$ & $f$ & $\%$ & & \\
\hline Malnutrition & 56 & 62.9 & 33 & 37.1 & 89 & 51.7 & \multirow[t]{3}{*}{0.001} & \\
\hline $\begin{array}{c}\text { Good } \\
\text { nutrition }\end{array}$ & 30 & 36.1 & 53 & 63.9 & 83 & 48.3 & & \\
\hline Total & 86 & 100 & 86 & 100 & 172 & 100 & & \\
\hline
\end{tabular}




\section{REFERENCES}

1. K. Mulholland, "Global burden of acute respiratory infections in children: Implications for interventions," Pediatr. Pulmonol., vol. 36, no. 6, pp. 469-474, Dec. 2003, doi: 10.1002/ppul.10344.

2. T. K. P. Nguyen, T. H. Tran, C. L. Roberts, G. J. Fox, S. M. Graham, and B. J. Marais, "Risk factors for child pneumonia - focus on the Western Pacific Region," Paediatr. Respir. Rev., vol. 21, pp. 95-101, Jan. 2017, doi: 10.1016/j.prrv.2016.07.002.

3. Y. A. Amrulloh, U. R. Abeyratne, V. Swarnkar, D. Herath, R. Triasih, and A. Setyati, "HMM Based Cough Sound Analysis for Classifying Pneumonia and Asthma in Pediatric Population," 2018, pp. 852-855.

4. N. N. Shampa, M. A. H. Mollah, M. M. Billah, A. L. Kabir, and N. C. Saha, "Comparative Study of Nutritional Status of Children (02-24 Months) with Acute Bronchiolitis and Pneumonia," J. Bangladesh Coll. Physicians Surg., vol. 35, no. 1, pp. 9-14, May 2017, doi: 10.3329/jbcps.v35i1.32565.

5. I. M. ZULFA, "Appropriateness Of Antibiotics Prescribed To Children And Adolescence With Bronchopneumonia During 2016 At A Hospital In Bangkalan, Indonesia," Sci. J. Farm. dan Kesehat., vol. 10, no. 1, p. 83, Feb. 2020, doi: 10.36434/scientia.v10i1.241.

6. R. Lodha, S. K. Kabra, and R. M. Pandey, "Antibiotics for community-acquired pneumonia in children," Cochrane Database Syst. Rev., Jun. 2013, doi: 10.1002/14651858.CD004874.pub4.

7. T. Heiskanen-Kosma, M. Korppi, C. Jokinen, and K. Heinonen, "Risk Factors for Community-acquired Pneumonia in Children: A Population-based Case-control Study," Scand. J. Infect. Dis., vol. 29, no. 3, pp. 281-285, Jan. 1997, doi: 10.3109/00365549709019043.
8. I. Rudan, "Epidemiology and etiology of childhood pneumonia," Bull. World Health Organ., vol. 86, no. 5, pp. 408-416, May 2008, doi: 10.2471/BLT.07.048769.

9. B. Spellberg and J. E. Edwards, "Type 1/Type 2 Immunity in Infectious Diseases," Clin. Infect. Dis., vol. 32, no. 1, pp. 76102, Jan. 2001, doi: 10.1086/317537.

10. C. K. Lutter and J. A. Rivera, "Nutritional Status of Infants and Young Children and Characteristics of Their Diets," J. Nutr., vol. 133, no. 9, pp. 2941S-2949S, Sep. 2003, doi: 10.1093/jn/133.9.2941S

11. A. CAMBROSIO, D. JACOBI, and P. KEATING, "Arguing with Images: Pauling's Theory of Antibody Formation," Representations, vol. 89, no. 1, pp. 94-130, Feb. 2005, doi: 10.1525/rep.2005.89.1.94.

12. P. C. Calder, "Feeding the immune system," Proc. Nutr. Soc., vol. 72, no. 3, pp. 299-309, Aug. 2013, doi: 10.1017/S0029665113001286.

13. J. A. G. Scott, W. A. Brooks, J. S. M. Peiris, D. Holtzman and E. K. Mulhollan, "Pneumonia research to reduce childhood mortality in the developing world," J. Clin. Invest., vol. 118, no. 4, pp. 1291-1300, Apr. 2008, doi: 10.1172/JCI33947.

14. S. R. C. Howie et al., "Childhood pneumonia and crowding bed-sharing and nutrition: a case-control study from The Gambia," Int. J. Tuberc. Lung Dis., vol. 20, no. 10, pp. 14051415, Oct. 2016, doi: 10.5588/ijtld.15.0993.

15. M. J. Chisti, M. Tebruegge, S. La Vincente, S. M. Graham, and T. Duke, "Pneumonia in severely malnourished children in developing countries - mortality risk, aetiology and validity of WHO clinical signs: a systematic review," Trop. Med. Int. Heal., vol. 14, no. 10, pp. 1173-1189, Oct. 2009, doi: 10.1111/j.1365-3156.2009.02364.x. 